Dual energy $x$-ray absorptiometry measurement of bone mineral content in newborns: validation of the technique. Pediatr Res 32:77-80

30. Audi L, Carrascosa A, Ballabriga A 1984 Androgen metabolism by human epiphyseal cartilage and its chondrocytes in primary culture. J Clin Endocrinol Metab 58:819-825

31. Corvol MT, Carrascosa A, Tsagris L, Rappaport R 1987 Evidence for a direct in vitro action of sex steroids on rabbit cartilage cells during skeletal growth: influence of age and sex. Endocrinology 120:1422-1429

32. Carrascosa A, Audi L, Ferrandez MA, Ballabriga A 1990 Biological effects of androgens and identification of specific dihydrotestosterone-binding sites in cultured human fetal epiphyseal chondrocytes. J Clin Endocrinol Metab 70:134-140

33. Ernst M, Schmid C, Froesch ER 1988 Enhanced osteoblast proliferation and collagen gene expression by estradiol. Proc Natl Acad Sci USA 85:23072310

34. Kasperk Ch, Fitzsimmons R, Strong D, Mohan S, Jennings J, Wergedal J, Baylink D 1990 Studies of the mechanism by which androgens enhance mitogenesis and differentiation in bone cells. J Clin Endocrinol Metab $71: 1322-1329$

\title{
Announcement
}

\section{Research on Hair Testing for Drugs of Abuse}

The National Institute on Drug Abuse has an interest in research on the utility of hair as a specimen for the detection of drugs of abuse. The goals of this program are to encourage systematic research on the use of hair testing to detect drugs of abuse in an accurate and reliable manner and to develop the necessary procedures and safeguards. Specific areas of interest are pharmacologic studies, analytical studies, and cost/benefit ratio analyses. Further information may be obtained from Rao S. Rapaka, Ph.D., or M. Beth Grigson Babecki, M.A., Division of Basic Research, National Institute on Drug Abuse, 5600 Fishers Lane, Room 10A-31, Rockville, MD 20857, (301) 443-6975. (Program announcement no. PA-92-18, November 1, 1991-November 1, 1994) 